\title{
Aquifer properties of the Chalk of England
}

\author{
ALAN M. MACDONALD ${ }^{1}$ \& DAVID J ALLEN ${ }^{2}$ \\ ${ }^{1}$ British Geological Survey, Murchison House, West Mains Road, Edinburgh, EH9 3LA, amm@bgs.ac.uk. \\ corresponding author \\ ${ }^{2}$ British Geological Survey, MacLean Building, Crowmarsh Gifford, Wallingford, Oxfordshire, OX10 8BB.
}

\begin{abstract}
Aquifer properties data from 2100 pumping tests carried out in the Chalk aquifer have been collated as part of a joint British Geological Survey / Environment Agency project. The dataset is highly biased: most pumping tests have been undertaken in valley areas where the yield of the Chalk is highest. Transmissivity values from measured sites give the appearance of log-normality, but are not truly lognormal. The median of available data is $540 \mathrm{~m}^{2} / \mathrm{d}$ and the 25th and 75th percentiles $190 \mathrm{~m}^{2} / \mathrm{d}$ and 1500 $\mathrm{m}^{2} / \mathrm{d}$ respectively. Estimates of storage coefficient from unconfined tests have a median of 0.008 and from confined tests, 0.0006 .
\end{abstract}

The data indicate several trends and relationships in Chalk aquifer properties. Transmissivity is highest in the harder Chalk of Yorkshire and Lincolnshire (median $1800 \mathrm{~m}^{2} / \mathrm{d}$ ). Throughout much of the Chalk aquifer a direct relation is observed between transmissivity and storage coefficient, reflecting the importance of fractures in governing both storage and transmissivity. Pumping tests undertaken in unconfined conditions give consistently higher measurements of transmissivity than in confined areas, probably as a result of increased dissolution enhancement of fractures in unconfined areas. At a catchment scale the data illustrate a relation between transmissivity and winter flowing streams.

Word Count $\quad 7500$ 
The Chalk is the most important aquifer within the UK. It accounts for $60 \%$ of the groundwater used in England and Wales and 20\% of the total water used in England and Wales (UK Groundwater Forum 1998). To protect and manage this unique resource it is essential to know and understand the variations of aquifer properties throughout the Chalk.

Against this background a three-year collaborative project between the British Geological Survey (BGS) and the Environment Agency (EA) was devised. The aim of the study was to collect, collate and present information concerning the physical properties of the major aquifers in England and Wales (Allen et al. 1997). This included creating a database of available pumping tests for the major aquifers. This paper presents an analysis and interpretation of all available Chalk data in the Aquifer Properties Database.

\section{OVERVIEW OF THE DEVELOPMENT OF CHALK AQUIFER PROPERTIES}

The presence and development of fractures gives the Chalk the properties of an aquifer. Without fractures, the permeability and specific yield of the Chalk would be negligible. Furthermore, without solution enhancement of the fractures, the high transmissivity of the Chalk would be impossible, and without further concentration of groundwater flow and dissolution of chalk, conduits and karstic features would not be observed. The Chalk is often referred to as possessing dual porosity (Price 1987; Barker 1991; Price et al. 1993). In a classic dual porosity aquifer, the matrix pores provide the storage, and the fractures provide the permeable pathways to permit groundwater flow. Groundwater movement within the Chalk is more complex: the high porosity (produced by the coccoliths) is not readily drained, due to the very small pore throats (Price et al. 1976), therefore effective groundwater storage is primarily within the fracture network and the larger pores.

The distribution of aquifer properties in the Chalk has been roughly known for at least the past 50 years. Woodland (1946) in a study of the hydrogeology of East Anglia, recognised the relation between 
transmissivity and topography. Ineson (1962) estimated transmissivity from specific capacity data to produce maps of transmissivity variation over the Chalk. The most pronounced feature of these was the correspondence of high transmissivity values with valley bottoms - with particularly high values at valley confluences. In East Anglia, Ineson suggested that the effect persisted downdip where the Chalk was overlain by younger deposits. Other maps of transmissivity have been produced for the London Basin (Water Resources Board 1972) and the Kennet Valley (Owen \& Robinson 1978). More recently, there has been a renewed interest in the regional distribution of aquifer properties due to numerical models (e.g. Rushton et al. 1989; Cross et al. 1995). These models require information on aquifer properties from the interfluves as well as from the valley bottoms.

Many factors have contributed to the development of aquifer properties within the Chalk (Figure 1). The general topographic pattern of transmissivity variation has developed through a number of processes: the concentration of groundwater flux within valleys (Rhoades \& Sinacori 1941; Robinson 1976; Owen \& Robinson 1978; Price 1987; Price et al. 1993); the structure of the Chalk (Ineson 1962; Water Resources Board 1972; Price 1987; Price et al. 1993); and periglacial erosion, particularly within taliks (Higgenbottom \& Fookes 1971; Williams 1980; Gibbard 1985; Williams 1987; Younger 1989). Superimposed upon the general distribution are other effects which sometimes result in high permeability and even karstic behaviour (Banks et al. 1995; MacDonald et al. 1998). The lithology of the Chalk has an important effect on aquifer properties, especially the presence of marl layers, flints or hardgrounds (Price 1987; Buckley et al. 1989; Lowe 1992; Mortimore 1993; Bloomfield 1997). The local structure of the Chalk can also affect the aquifer properties, depending on whether significant fracturing has developed and also the presence or absence of fault gouge (Houston et al. 1985; Giles \& Lowings 1990; Mortimore 1993). Palaeogene, or other younger cover, can be instrumental in developing solution features and groundwater conduits, as can the recent or historic presence of rivers, and periglacial activity (Fagg 1958; Atkinson \& Smith 1974; Walsh \& Ockenden 1982; Price et al. 1992; Banks et al. 1995; MacDonald et al. 1998; Lamont-Black \& Mortimore 1999). Hiscock \& Lloyd (1992) report the importance of glacial till within East Anglia in restricting groundwater flow and therefore the development of transmissivity. 
Buried channels within the Chalk of East Anglia also affect Chalk aquifer properties, however their effect on the hydrogeology is variable and dependent on the composition of the fill (Foster \& Robertson 1977).

\section{CHALK PUMPING TEST DATA}

\section{Data Collection}

Various data from Chalk pumping tests were collected as part of the BGS/EA Aquifer Properties Review (Allen et al. 1997). Data were collected primarily from test pumping reports and files kept at regional Environment Agency offices, with some additional data from Water Companies and BGS records. Requisite data for each test included the location and national grid coordinates of the test, the aquifer tested, and at least one measurement of transmissivity or storage coefficient. Secondary data were collected and databased including: pump test details (e.g. date, rest-water-level, pumping-water-level, test length, pumping rate, presence of observation boreholes, test analysis details etc.); borehole construction details (e.g. diameter, depth, casing depth etc.); and comments on the data with a subjective measure of confidence in the test results. Auxiliary data were also collected but not digitised; these generally concerned the availability of geophysical logs and depths to fractures.

\section{Data pre-analysis and quality}

Approximately 6000 estimates of transmissivity were recorded from 2200 pumping tests; 3000 estimates of storage coefficient were collected from about 1300 tests. Such a large number of duplicate estimates for each pumping test is primarily due to two factors: (1) data being analysed from various observation boreholes; and (2) the variety of analysis techniques available for interpreting drawdown data. For tests with multiple estimates, a procedure was followed to identify single representative values of aquifer parameters for each test. This gave priority to observation borehole data and interpretations using 
appropriate analysis. This procedure was followed to give a single estimate of transmissivity for each of the 2200 tests. The database was audited to ensure that the calculated single values were not spurious (Allen et al. 1997).

The quality of pumping tests was highly variable. Some estimates of transmissivity were calculated from drawdown monitored in dedicated observation boreholes over several weeks of highly controlled pumping. Others were made from measured drawdown in an abstraction borehole after one or two hours of erratic pumping. A general assessment of the quality of pumping test data was made during data collection where there was sufficient raw data to make a judgement. This was a subjective measure, based on factors such as variations in pumping rate, or the fit of data to the model used in analysis (Allen et al. 1997). Therefore, a quality rating could only be given where there was access to original data, and data collection was made by a qualified hydrogeologist. Quality ratings were obtained for 1180 tests (approximately $56 \%$ of the data). These were roughly normally distributed over the quality range (see Figure 2). Twenty-two percent of the tests for which it was possible to estimate quality, were rated as good or very good, and $12 \%$ as very poor. The bulk of the quality ratings were moderate or fair.

For each value of transmissivity in the database, the source of the data was indicated; for example, a constant rate test of more than 1 day, or a constant rate test with observation boreholes. Figure 3 shows the impact of the type of test on the measured value of transmissivity. Highest estimates of transmissivity were obtained using constant rate tests with: (1) observation borehole data; or (2) a high degree of subjective quality; or (3) durations longer than one day. Data with these characteristics also varied the least from test to test and location to location. This trend is unlikely to be due to inherent bias from the different pumping test methods, but probably reflects the natural clustering of good quality pumping tests to the more productive areas of the Chalk aquifer. Much lower estimates of transmissivity were estimated from constant rate tests that were: (1) carried out for less than a day; or (2) of very poor quality; or (3) had no information about the source of the data. The variance of test results was also significantly higher from data with these characteristics. Data from these poorer pumping tests, however, are of particular 
value in describing Chalk aquifer properties. Short tests are often conducted in small farm boreholes or pilot and observation boreholes. Some of these boreholes are abandoned after the first test because of low yields, or in the case of a farm borehole, a long test is not required. The true value of these tests is their location - away from the main producing valleys and scattered throughout the Chalk outcrop. Therefore, it was considered important to keep these poorer quality data within the data set - and not to remove them in favour of the better data. Only by including these tests can indication be given of the aquifer properties of the Chalk in the less developed areas.

More than one pumping test had been carried out at several hundred boreholes. Duplicate pumping tests in single boreholes were kept as separate entries in the dataset in order to reflect the three dimensional variation in Chalk aquifer properties. Transmissivity can vary non-linearly with depth, therefore with only a few metres change in water-level the aquifer properties can alter significantly. At over $90 \%$ of the sites, transmissivity measurements changed by more than $25 \%$ between different tests. Therefore it was thought that the range in Chalk aquifer properties would be better reflected by keeping different tests on the same borehole as separate entries in the dataset. However, if one of the tests was of particularly poor quality (i.e. given a low confidence value in the data collection), or from a step drawdown test, it was omitted. A few boreholes had many ( $>10)$ pumping tests carried out on them. At these sites the number of tests included was reduced to avoid unnecessarily biasing the data.

\section{General Statistics}

The filtering process reduced the dataset to 2100 measurements of transmissivity and 1200 estimates of storage coefficient. The distribution of transmissivity measurements is given in Figure 4 and of storage coefficient measurements in Figure 5. Both distributions give the appearance of log-normality. However, testing the data for normality using a Kolmogorov-Smirnoff test indicated that neither dataset truly follows a log-normal distribution. 
The distribution of transmissivity measurements is shown in Figure 4. The data are skewed towards higher values. The median value of the data is $540 \mathrm{~m}^{2} / \mathrm{d}$; the 25 th and 75 th percentiles are $190 \mathrm{~m}^{2} / \mathrm{d}$ and $1500 \mathrm{~m}^{2} / \mathrm{d}$ respectively. These data reflect the favourable aquifer properties in the Chalk. However, data are heavily biased towards high value sites so should not be treated as indicative of the aquifer properties of the entire Chalk, but only of the measured sites. The bias of the data set is discussed in more detail later.

Estimates of storage coefficient from 1200 tests are shown in Figure 5. The data show slight bimodality and there are few estimates of storage coefficient less than $10^{-4}$ or greater than 0.1 . The median value of storage coefficient from pumping tests is 0.0023 , and the 25th and 75th percentile $4 \times 10^{-4}$ and 0.01 respectively. Further investigation of the variation of storage coefficient in relation to differing degrees of aquifer confinement is reported later.

Specific capacity has been calculated for 802 boreholes which also have estimates of transmissivity. Corrections were made for the radius of the borehole (Ineson 1959), but insufficient data were available to correct for non-steady state conditions. However, since $75 \%$ of the specific capacity data were calculated from tests of more than 1 day, this error should not be large. Acidisation of Chalk boreholes has a large effect on the specific capacity. Banks et al. (1993) show that for most Chalk boreholes, the removal of slurry by acidisation can increase the specific capacity by on average about 2 times and sometimes in excess of 20 times. Unfortunately, no information concerning acidisation is currently available digitally. However, since it is common practice to acidise boreholes drilled in the Chalk (Banks 1993; Monkhouse 1995) it can be assumed that the majority of specific capacity data quoted is for acidised boreholes.

From the available data, a broad relation between specific capacity and transmissivity can be given for the Chalk aquifer as a whole (Figure 6). Regression of the data gives the empirical relation $T=12.5(\mathrm{Q} / \mathrm{s})^{0.71}$ with a significant, but weak correlation $\left(r^{2}=0.48\right)$. This empirical relation differs from the widely used Logan's approximation, $T=1.22$ (Q/s) (Logan 1964). The Chalk data suggest that Logan's 
approximation underestimates transmissivity at low specific capacity (Figure 6). However, a study of specific capacity and transmissivity in an alluvial aquifer found a similar relation to that of the Chalk data. Razack \& Huntley (1991) found transmissivity to be related to specific capacity through the equation $T=$ $15.3(\mathrm{Q} / \mathrm{s})^{0.67}$ for 215 boreholes.

A summary of some of the additional data collected for the Chalk boreholes in the aquifer properties database is shown in Table 1. Most of the data have been found to have no significant statistical correlation with measured aquifer properties.

\section{Special considerations for pumping test analysis in the Chalk}

Many authors have illustrated that classical pumping test analysis is possible in fractured rocks subject to several basic conditions (e.g. Snow 1968; Barker 1991). The approach involves the replacement of the fractured media with a representative continuum in which values of aquifer properties can be assigned. A sufficiently large section of the aquifer needs to be tested to ensure that a representative measure of aquifer properties is given. A borehole that does not penetrate the important flowing fractures will not give a representative measurement of aquifer properties of the area. This is especially important in the Chalk where boreholes a few metres apart may penetrate different fracture systems and consequently give very different measures of aquifer properties.

The location of observation boreholes is also important for pumping test analysis in the Chalk. Spurious interpretations can be given if observation boreholes intersect a different fracture system from the abstraction borehole. In the Chalk, this can often occur in dry valleys. Observation boreholes on the side of the valley may not respond at all to pumping within the valley floor. Interpretation may suggest a very high transmissivity perpendicular to the valley, when in reality the opposite is the case.

Another important factor to consider when analysing pumping tests within the Chalk is the time scale over 
which water moves in response to pumping. In many pumping tests, a delayed yield response is observed even where the Chalk is not overlain by another aquifer (MacDonald 1997; Jones et al. 1993). This suggests that extra water is being added to the aquifer during pumping complicating the analysis. The source of this water is unclear, but may be due to leakage from the unsaturated zone (Price et al. 2000), leakage from the Chalk at depth, recharge from constant head boundaries or water moving from the matrix and smaller fractures to the larger flowing fractures.

\section{Data bias}

The distribution of all available data is shown in Figure 7. It is immediately apparent that the data are not evenly spread over the Chalk outcrop. The majority of the data are clustered within East Anglia, with a much lower density over the Hampshire and Thames Basins and to the north in Yorkshire and Lincolnshire. This reflects the higher demand for groundwater in East Anglia, for both public water supply and irrigation.

At a catchment scale, data are even less randomly distributed. Throughout the Chalk outcrop, boreholes (and therefore aquifer properties data) tend to be clustered within valleys. Few boreholes are drilled for the sole purpose of measuring aquifer parameters. Generally boreholes are drilled for water supply; pumping tests are then carried out to estimate the likely behaviour of the borehole under various scenarios. Consequently, boreholes are located in areas where demand for groundwater is high and the aquifer properties favourable - usually valleys.

This bias towards favourable aquifer conditions creates a significantly unbalanced dataset. For example, the median of all transmissivity values calculated for the 2100 pumping tests in the Chalk is approximately $540 \mathrm{~m}^{2} / \mathrm{d}$; this implies that a borehole drilled at random into the Chalk would have a $50 \%$ probability of gaining a transmissivity of greater than $540 \mathrm{~m}^{2} / \mathrm{d}$. This is patently not the case over most of the outcrop area of the English Chalk. 
There is little that can be done to redress the bias in the data set, without deliberately drilling and testing low yielding areas. However, several small steps were taken to try and ensure that the bias was not compounded. First, to combat the undue emphasis of data in East Anglia, the data were split into smaller units according to physical features rather than data distribution. Thus, the data were divided into four subsets taking into account the depositional, structural and glacial history. The bias towards high yielding valley sites is particularly problematic. There are very few pumping tests in interfluve areas, and those that do exist tend to be poor quality tests from farm boreholes or abandoned trial boreholes. Good quality, data rich, tests are generally only carried out on highly productive boreholes. As discussed above, the pre-analysis of the data was designed in such a way that poorer quality tests carried out in low yielding areas were not removed from the dataset. However, these small steps still leave the data highly biased. It is therefore important to recognise that the data are representative of measured sites rather than the Chalk aquifer as a whole.

\section{DATA TRENDS AND INTERPRETATION}

\section{Regional Distribution of aquifer properties}

The Chalk outcrop has been divided into four different geographical regions to help the description and analysis of the aquifer properties distribution. Various factors were considered including the depositional, structural and glacial history (Bloomfield et al. (1995) used the same divisions in describing trends in the matrix properties of the Chalk). As discussed above, by dividing the Chalk on physical grounds, some of the problems arising from the clustering of the data should be overcome. The four regions are: (1) Southern; (2) the Thames Basin (including the North Downs); (3) East Anglia; and (4) Yorkshire and Lincolnshire (Figure 8). The distribution of transmissivity and storage coefficient data (test values) for the four regions are shown in Figure 9 and 10. 
The transmissivity distribution shows broad similarities over the four regions. Data approximate to a lognormal distribution in all regions, but are not truly log-normal as defined by the Kolmogorov-Smirnoff normality test. There is a scattering of data points extending to low transmissivity, but the high transmissivity tail is cut off abruptly. This truncation reflects both the difficulties in measuring extremely high transmissivity values and the physical impracticability of gaining high values due to turbulent flow.

To help identify differences between the data distributions for the four regions, the cumulative frequency distributions are re-plotted together on Figure 11. Data from each region were also compared using the Mann-Whitney test for non-parametric data. This indicated that the data samples from Thames and East Anglia had a 95\% probability of being from the same population. No other statistically meaningful correlation was found between data from other regions.

From the cumulative frequency plots on Figure 11 it is apparent that data from Yorkshire and Lincolnshire show distinctly different aquifer properties from the rest of the Chalk. Transmissivity is significantly higher (median $1800 \mathrm{~m}^{2} / \mathrm{d}$ ) and the storage coefficient much lower (see Figure 10). The storage coefficient shows bimodality, representing a clear distinction between confined and unconfined Chalk. (The variation of storage coefficient from confined to unconfined conditions is discussed in more detail later). Even accounting for much of the data being from the confined aquifers, the measurements of storage coefficient are lower than for other areas of the Chalk. These different aquifer properties demonstrate the distinctiveness of the northern Chalk. As discussed above, data from East Anglia and Thames have similar distributions of transmissivity (median $410 \mathrm{~m}^{2} / \mathrm{d}$ and $580 \mathrm{~m}^{2} / \mathrm{d}$ respectively) and storage coefficient. Both areas have a high degree of exploitation, therefore probably have more data from poorer yielding areas of Chalk. Data from the South indicate higher transmissivity than East Anglia and Thames (median $1000 \mathrm{~m}^{2} / \mathrm{d}$ ), but similar estimates of storage coefficient.

The data were subdivided into 17 smaller areas to try to investigate further the regional distribution 
(Figure 8). Again, the subdivisions were made on purely physical grounds, comprising either discrete blocks or catchments. Summary data for the areas are shown in Table 2 and Figure 12. Yorkshire and Lincolnshire again show high transmissivity values. The high transmissivity values for the Southern area are shown to be caused mainly by pumping tests in the Salisbury Plain and Hampshire. Relatively few locations have been tested in these areas, therefore the data may be biased towards higher yielding areas. Giles and Lowings (1990) suggested a link between folding in the Hampshire area and high transmissivity. However, the lower transmissivity areas of Dorset and the South Downs have been subjected to more folding than either Hampshire or Salisbury Plain. Clearly other mechanisms must also be significant. Lowest median transmissivity values are found in the London area, East Norfolk and East Suffolk. These three areas of the Chalk aquifer have significant cover and are in some places confined.

Variations in storage coefficient across the outcrop are shown in Figure 12b. Lincolnshire has significantly lower storage than other areas of Chalk. Although the Chalk in Lincolnshire is largely confined, other areas with much confined data (such as London, East Norfolk and East Suffolk) show much higher values of storage coefficient. The most plausible explanation for the low storage in Lincolnshire, is the different chalk lithology. Lower porosity and harder Chalk (Foster \& Crease 1974; Barker 1994; Bloomfield 1995) will significantly reduce the elastic storage. Since confined storage depends wholly on elastic storage, the measured storage coefficient would be very low. However, when the northern Chalk becomes unconfined (such as in the Yorkshire Wolds, gravity drainage from fractures becomes significant and the measured storage coefficient becomes less dissimilar to those measured in areas of softer Chalk.

A distinct correlation is observed between transmissivity and storage coefficient in Figure 12. To explore the nature of this relationship, median transmissivity and storage coefficient for each area are cross plotted in Figure 13. This clearly demonstrates that median transmissivity and storage coefficient for each area are directly related. Only Lincolnshire lies outside this trend, which may again point to a reduction in elastic storage in the northern Chalk. The general trend observed for all other areas demonstrates the 
importance of fractures for both storage and transmissivity.

\section{Valley/interfluve}

It has long been accepted that borehole yields in the Chalk are higher in valleys than over interfluves and that transmissivities tend to follow a similar pattern (e.g. Woodland 1946; Ineson 1962). It is therefore pertinent to examine the extent to which the pumping test data set support this experience.

One of the easiest ways to test variations in transmissivity from valley to interfluve is to examine the correlation between transmissivity and depth to rest-water-level (RWL), as RWLs are shallower in valleys than interfluves. However when this analysis was performed on the Chalk data no significant correlation was found. The reason for this is probably the significant bias in the data set to valley sites, as discussed earlier. In order to minimise this bias therefore, an area was chosen that had a reasonable spread of data away from the high yielding valleys. A suitable area was the Kennet Valley, where the Chalk was subject to a large investigation in the 1970's as part of the Thames groundwater scheme (Thames Water Authority 1978). During this study a series of abstraction and observation boreholes were drilled, some of which were deliberately located in interfluve areas. Consequently, the Kennet Valley is one of the few areas of Chalk with a relatively unbiased spread of data.

Robinson (1976) predicted transmissivity variations in the area under low water-table conditions using several factors - primarily distance from winter flowing streams, modified by depth to minimum RWL and thickness of Upper and Middle Chalk. He achieved a good correlation between the predicted results and those from high quality pumping tests carried out under minimum water-table conditions.

The current full data set was analysed for transmissivity trends within the Kennet Valley using a Geographical Information System. Measured transmissivity values from pumping tests throughout the valley were compared to four variables: distance from winter flowing streams, depth to RWL, saturated 
thickness of Upper and Middle Chalk and distance from Eocene deposits. Multiple regression was used to find relationships between transmissivity and combinations of these variables. From this analysis, distance from winter flowing streams on its own was found to predict transmissivity best (Figure 14). No other variable, or combination of variables, gave as significant a correlation (it should be noted however that the correlation is still weak $\left.\left(r^{2}=0.43\right)\right)$.

It is concluded from the above that the data examined broadly support the traditional view of valley/interfluve transmissivity distribution, even when unfiltered for quality or factors such as test length or seasonal rest water level. The correlations are, however, insufficient to be used for predictive purposes. This is probably partly because of the absence of rigorous data filtering and partly because factors other than those considered (e.g. Quaternary history, degree of confinement, lithology) may be involved.

\section{Confined and unconfined conditions}

The database was used to examine variations in both transmissivity and storage coefficient with the degree of confinement of the aquifer. A subset of the dataset was selected that had information available on the degree of confinement of the aquifer. The subset contained about 900 pumping tests with sufficient information available to divide the tests into confined, semi-confined and unconfined. The geographical distribution of this subset followed approximately the distribution of the entire Chalk dataset (with the exception of the northern area which had negligible confined/unconfined information). However, there was a slight bias in the data towards East Anglia for the confined data, and Thames and Southern areas for the unconfined data. Since the Thames and East Anglian data form approximately $90 \%$ of the subset and have very similar data distributions (see Figure 11) this bias is not significant.

Not surprisingly, the storage coefficient shows significant differences between measurements taken in confined and unconfined conditions (Figure 15). The median of confined pumping tests is 0.0006 and of unconfined tests 0.008 ; semi-confined tests have intermediate values. A summary of the data is given in 
Table 3. Values from confined Chalk agree with detailed research into Chalk storage undertaken by Lewis et al. (1993). They calculated the specific storage of the Chalk to be $1.5 \times 10^{-5} \mathrm{~m}^{-1}$, which integrated over a $100 \mathrm{~m}$ thickness of Chalk aquifer gives a storage coefficient for confined Chalk of 0.0015

Estimates of storage coefficient from unconfined pumping tests are also broadly similar to those estimated from groundwater-level recession analysis by Lewis et al. (1993). For the top $30 \mathrm{~m}$ of saturated Chalk, they estimated the storage coefficient as 0.005 to 0.05 , which compares favourably with the unconfined pumping test inter-quartile range of 0.0028 to 0.017 . The slightly lower values from the pumping tests may be attributed to delayed recharge from the unsaturated zone, which may not be observed in short pumping tests.

The small difference between confined and unconfined storage illustrates the relative importance of elastic storage in the Chalk. The Chalk aquifer is highly compressible (Carter \& Mallard 1974; Price et al. 1993) hence the high estimates of specific storage by Lewis et al. (1993) and the corresponding high values of storage coefficient measured from confined pumping tests. In unconfined situations, the specific yield is limited by the small proportion of Chalk pores that can drain under gravity - less than $1 \%$ of the Chalk bulk volume (Price et al. 1976; Price 1987) and the limited volume of groundwater stored in fractures. Therefore, in unconfined conditions, the elastic storage is still relatively important.

Transmissivity measurements also show a distinct difference between confined and unconfined pumping tests (Figure 15). Unconfined tests have an interquartile range of 310 to $2250 \mathrm{~m}^{2} / \mathrm{d}$ (median $920 \mathrm{~m}^{2} / \mathrm{d}$ ), while confined tests have an interquartile of 66 to $620 \mathrm{~m}^{2} / \mathrm{d}$ (median $220 \mathrm{~m}^{2} / \mathrm{d}$ ). Semi-confined measurements of transmissivity were marginally higher than those measured under confined conditions: interquartile range 115 to $720 \mathrm{~m}^{2} / \mathrm{d}$ (median $280 \mathrm{~m}^{2} / \mathrm{d}$ ). These data indicate that transmissivity is significantly more developed in unconfined Chalk than in confined or semi-confined Chalk. This also helps to explain the regional trends detailed in Table 2. The areas with the lowest measurements of 
transmissivity (East Norfolk, East Suffolk and London) are also the areas where Chalk is most heavily confined; in East Norfolk and East Suffolk by Crag, and in the London Basin by Eocene deposits.

Since transmissivity is largely governed by solution enhanced fractures, it is logical to conclude that in the confined (and probably semi-confined) areas of the Chalk aquifer, the solution enhancement of fractures has not developed to the same extent. These data agree with Hiscock \& Lloyd's (1992) study of permeability development in areas overlain by thick drift. They show that significant permeability development probably took place in the last 5000 years; however in areas covered by thick drift, or confined by younger deposits, permeability would not have been significantly enhanced. The origin of the solution enhanced fractures observed in deeply confined Chalk is unclear. They may have developed in Eocene times, and enhanced with groundwater flow during glacial periods; slow groundwater flux may also help to enhance permeability. Local development of solution enhanced fractures may be related to discrete outlets through the confining cover. Some of these may have operated to greater effect during periods of lower sea level and glaciation. Palaeohydrogeological studies could greatly enhance understanding of the distribution of aquifer properties.

\section{SUMMARY AND CONCLUSIONS}

The collection and systematic databasing of pumping test data for the Chalk of England has allowed a unique opportunity for studying the Chalk aquifer. Aquifer properties data exist for 2100 pumping tests in the Chalk. The data are of variable quality; only $22 \%$ of the tests were rated as being of good or very good quality. The distribution of the data is also highly biased. The majority of tests have been carried out in high yielding valley sites, with little coverage over interfluve areas. Although interfluve areas are generally low yielding, rapid contaminant pathways may exist (Allen et al._1997, MacDonald et al. 1998). Therefore, to protect groundwater resources within the Chalk aquifer it is important to understand the aquifer properties distribution in interfluves as well as valleys. Knowing aquifer properties in low 
yielding areas is also important for building regional models of Chalk aquifer. The lack of data in these areas introduces large uncertainty into these models. Therefore, there is a need to carry out more controlled testing in low yielding areas.

Analysis of the 2100 pumping tests available for the Chalk aquifer shows that although the data approximate to a log-normal distribution, they are not truly log-normal. The median value of measured transmissivity values is $540 \mathrm{~m}^{2} / \mathrm{d}$. Average measured transmissivity values are highest in the northern Chalk of Yorkshire and Lincolnshire (median $1800 \mathrm{~m}^{2} / \mathrm{d}$ ) which may reflect the different diagenetic and structural development of the northern Chalk. Transmissivity values were also found to vary significantly between confined and unconfined sites. Unconfined sites tended to have higher transmissivity (median $920 \mathrm{~m}^{2} / \mathrm{d}$ ) than confined sites (median $220 \mathrm{~m}^{2} / \mathrm{d}$ ). This may reflect increased solution enhancement of fractures under unconfined conditions. Analysis of a subset with data available for both interfluves and valleys showed a correlation between transmissivity values and distance from winter flowing strams. However, the correlation was slight, therefore factors other than distance from valleys must play a role in developing aquifer properties.

One thousand two hundred pumping tests had estimates of storage coefficient. Approximately one order of magnitude difference was recorded between confined and unconfined tests. Estimates of storage coefficient from unconfined tests had a median 0.008; and from confined tests, 0.0006 . The relatively small difference between the two measurements may be explained by the limited gravity drainage of the Chalk, and therefore the relative importance of elastic storage in both confined and unconfined conditions. However, gravity drainage from fractures is still a significant component of storage. This is illustrated by the direct relationship that exists between transmissivity and the storage coefficient. The fracture network, which controls transmissivity, also largely controls the storage of the Chalk. The Chalk in Lincolnshire does not follow this trend. This may be due to the lower elastic storage of the northern Chalk, compounded in Lincolnshire by the fact that the Chalk is confined. 
Understanding variations in aquifer properties is fundamental to understanding and modelling how groundwater and contamination occurs and moves within the Chalk aquifer. This study has shown how general trends can be seen from collating and interpreting all available pumping test data from the Chalk. However transmissivity and storage coefficient are only summaries of aquifer properties and are not good at predicting extreme behaviour, such as rapid groundwater flow, or complex behaviour such as matrix fracture interaction. Detailed field studies of various areas of the Chalk aquifer, such as interfluves and confined areas, may help to explain why such variations exist.

\section{Acknowledgements}

This paper is published by the permission of the Director, British Geological Survey (NERC). The helpful comments of V Robinson at the Environment Agency and I Gale and J Bloomfield at BGS are gratefully acknowledged. 


\section{References}

Allen, D. J., Brewerton, L. J., Coleby, L. M., Gibbs, B. R., Lewis, M. A., MacDonald, A. M., Wagstaff, S. J. \& Williams, A. T. 1997. The Physical Properties of Major Aquifers in England and Wales. British Geological Survey Technical Report WD/97/34.

Atkinson, T.C. \& Smith, D. I. 1974. Rapid groundwater flow in fissures in the chalk: an example from south Hampshire, Quarterly Journal of Engineering Geology, 7, 197-205.

Banks, D., Cosgrove, T., Harker, D., Howsam, P. \& Thatcher, J. P. 1993. Acidisation: borehole development and rehabilitation. Quarterly Journal of Engineering Geology, 26, 109-126.

Banks, D., Davies, C. \& Davies, W. 1995. The Chalk as a karstic aquifer: evidence from a tracer test at Stanford Dingley, Berkshire, UK, Quarterly Journal of Engineering Geology, 28, S31-S38.

Barker, J. A. 1991. Transport in fractured rock. In: Downing, R. A. \& Wilkinson, W. B. (eds) Applied Groundwater Hydrology, Clarendon Press, Oxford. 199-216.

Barker, R. D., 1994. Some hydrogeophysical properties of the Chalk of Humberside and Lincolnshire. Quarterly Journal of Engineering Geology, 27, S5-S14.

Bloomfield, J. P., Brewerton, L. J. \& Allen, D. J. 1995. Regional trends in matrix porosity and bulk density of the Chalk of England. Quarterly Journal of Engineering Geology, 28, S131-S142.

Bloomfield, J. P. 1997. The role of diagenesis in the hydrogeological stratification of carbonate aquifers: an example from the Chalk at Fair Cross, Berkshire, UK. Hydrology and Earth Science Systems, 1, 1934. 
Buckley, D. K., Cripps, A. R. \& Shedlock, S. L. 1989. Geophysical logging of SC Series boreholes to investigated pollution of a Chalk aquifer. British Geological Survey Technical Report WK/89/20R.

Carter, P. G. \& Mallard, D. J. 1974. A study of the strength, compressibility and density trends within the Chalk of southeast England.. Quarterly Journal of Engineering Geology, 7, 43-55.

Cross, G. A., Rushton, K. R. \& Tomlinson, L.M. 1995. The East Kent Chalk aquifer during the 1988-92 drought. Journal of the Institution of Water and Environmental Management, 9, 37-48.

Fagg, C.C. 1958. Swallow holes in the Mole gap, South East Naturalist and Antiquary, 62, 1-13.

Foster, S. S. D. \& Robertson, A. S. 1977. Evaluation of a semi-confined Chalk aquifer in East Anglia. Proceedings of the Institution of Civil Engineers, 63, 803-817.

Foster, S. S. D. \& Crease, R. I., 1974. Hydraulic behaviour of the Chalk aquifer in the Yorkshire Wolds. Proceedings of the Institution of Civil Engineers, 59, 181-188.

Gibbard, P. L. 1985. The Pleistocene history of the Middle Thames Valley. Cambridge University Press, Cambridge.

Giles, D.M. \& Lowings, V.A. 1990. Variation in the character of the chalk aquifer in east Hampshire. In: Burland J. B., Mortimore R. N., Roberts T. S., Jones D. L. \& Corbett B. O. (eds) Chalk, Thomas Telford, London, 619-626.

Higginbottom, I. E. \& Fookes, P. G. 1971. Engineering aspects of periglacial features in Britain. Quarterly Journal of Engineering Geology, 3, 85-117. 
Hiscock, K. M. \& Lloyd, J. W. 1992. Palaeohydrgeological reconstructions of the north Lincolnshire Chalk, UK for the last 140,000 years, Journal of Hydrology, 133, 313-342.

Houston, J. F. T., Eastwood, J. C. and Cosgrove, T. K .P. 1986. Locating potential borehole sites in a discordant flow regime in the Chalk aquifer at Lulworth using integrated geophysical surveys, Quarterly Journal of Engineering Geology, 19, 271-282.

Ineson, J., 1959. Yield depression curves of discharging wells, with particular reference to Chalk wells and their relationship to variations in transmissibility. Journal of the Institution of Water Engineers, 13, 119-163.

Ineson, J., 1962. A hydrogeological study of the permeability of the Chalk. Journal of the Institution of Water Engineers, 16, 449 - 463.

Jones, H. K., Gale, I. N., Barker, J. A. \& Shearer, T. R., 1993. Hydrogeological report on the test pumping of Hutton Cranswick, Kilham and Elmswell boreholes. British Geological Survey Technical Report, WD/93/9.

Lamont-Black, J. \& Mortimore, R. 1999. Predicting the distribution of dissolution pipes in the chalk of southern England using high resolution stratigraphy and geomorphological domain characterisation. In: Beck, B. F., Pettit, A. J. \& Herring, J. G. (eds) Hydrogeology and Engineering geology of sinkholes and karst. Balkema, Rotterdam, 97-102.

Lewis, M. A., Jones, H. K., Macdonald, D. M. J., Price, M., Barker, J. A., Shearer, T. R., Wesselink, A. J. \& Evans, D. J. 1993. Groundwater storage in British aquifers: Chalk. National Rivers Authority R\&D Note 128. 
Logan, J. 1964. Estimating transmissibility from routine production tests of water wells. Ground Water 2, 35-37.

Lowe, D. J. 1992. Chalk caves revisited. Cave Science, 19, 55-58.

MacDonald, A. M., Brewerton, L. J. \& Allen, D. J., 1998. Rapid groundwater flow and 'karst' type behaviour in the Chalk of England. In: Robins, N. S (ed.) Groundwater pollution, Aquifer Recharge and Vulnerability. Geological Society, London, Special Publications. 130 95-106.

MacDonald, A. M. 1997. Comparative analysis of pumping tests in the Chalk aquifer in Yorkshire and Lincolnshire. British Geological Survey Technical Report WD/97/25.

Monkhouse, R. A., 1995. Prediction of borehole yield in the confined Chalk of the London Basin. Quarterly Journal of Engineering Geology, 28, 171-178.

Mortimore, R. N. 1993. Chalk water and engineering geology. In: Downing, R. A., Price, M. \& Jones, G. P. (eds), The hydrogeology of the Chalk of north-west Europe. Clarendon Press, Oxford. 67-92.

Owen, M. \& Robinson, V. K. 1978. Characteristics and yield in fissured Chalk. Symposium on Thames Groundwater Scheme, Institution of Civil Engineers, London. 33-49.

Price, M., Bird, M. J. \& Foster, S. S. D. 1976. Chalk pore-size measurements and their significance. Water Services, October, 596-600

Price, M., 1987. Fluid flow in the Chalk of England. In: Goff, J. C. and Williams, B. P. J. (eds) Fluid Flow in Sedimentary Basins and Aquifers, Geological Society London Special Publications, 34, 141-156. 
Price, M., Atkinson, T. C., Barker, J. A., Wheeler, D. \& Monkhouse, R.A. 1992. A tracer study of the danger posed to a chalk aquifer by contaminated highway run-off, Proc. Instn. Civ. Engrs. Wat., Marit. \& Energy, 96, 9-18.

Price, M., Downing, R. A. \& Edmunds, W.M. 1993. The Chalk as an aquifer In: Downing, R. A., Price, M. \& Jones, G. P. (eds), The hydrogeology of the Chalk of north-west Europe. Clarendon Press, Oxford. $14-34$.

Price, M., Low, R. G. \& McCann, C. 2000. Mechanisms of water storage and flow in the unsaturated zone of the Chalk aquifer. Journal of Hydrology, 233, 54-71.

Razack, M. \& Huntley, D. 1991. Assessing transmissivity data from specific capacity data in a large and heterogeneous alluvial aquifer. Ground Water, 29, 856-861.

Rhoades, R. \& Sinacori, M. N. 1941. Pattern of groundwater flow and solution. Journal of Geology. 49, 785-794.

Robinson, V. K. 1976. The hydrogeological model of the Kennet Chalk aquifer, Thames Conservancy Division, Internal Report. Thames Water Authority, Reading.

Rushton, K. R, Connorton, B. J. \& Tomlinson, L. M. 1989. Estimation of the groundwater resources of the Berkshire Downs supported by mathematical modelling, Quarterly Journal of Engineering Geology, 22, 329-341.

Snow, D. T. 1968. Rock fracture spacings, openings and porosities, Journal Soil Mechanics, Foundation Divisions, Proceedings of the American Society of Civil Engineers, 94, 73-91. 
UK Groundwater Forum, 1998. Groundwater our hidden asset. British Geological Survey, Keyworth.

Thames Water Authority, 1978. The Thames Groundwater Scheme. Institution of Civil Engineers, London.

Water Resources Board, 1972. The hydrogeology of the London Basin, Water Resources Board, Reading.

Williams, R. B. G. 1980. The weathering and erosion of chalk under periglacial conditions. In: Jones, D. K. C. (ed.) The shaping of southern England, Academic Press, London, 225-248.

Williams, R.B.G., 1987. Frost weathered mantles on the Chalk: In: Boardman, J. (ed.) Periglacial processes and Landforms in Britain and Ireland, Cambridge University press, Cambridge, 127-133.

Walsh, P. T. \& Ockenden, A. C. 1982. Hydrogeological observations at the Water End swallow hole complex, North Mimms, Hertfordshire, Cave Science, 9, 184-194.

Woodland, A. W. 1946. Water supply from underground sources of the Cambridge-Ipswich district. Geological Survey Wartime Pamphlet, 20.

Younger, P. L., 1989. Devensian periglacial influences on the development of spatially variable permeability in the Chalk of southeast England. Quarterly Journal of Engineering Geology, 22, 343-345. 


\section{List of Tables}

Table $1 \quad$ Summary of borehole and pumping test details for the Chalk of England.

Table 2 Summary statistics for the aquifer properties of the Chalk of England.

Table 3 Summary statistics for confined and unconfined measurements of the aquifer properties of the Chalk.

\section{List of Figures}

Figure 1 The development of aquifer properties in the Chalk of England.

Figure 2 Distribution of quality ratings for Chalk pumping test data.

Figure 3 The mean and variance of transmissivity estimates from different quality pumping tests.

Figure 4 Distribution of transmissivity data from tests in the Chalk aquifer.

Figure 5 Distribution of storage coefficient data from tests in the Chalk aquifer.

Figure 6 The relation between specific capacity data (corrected for radius, but not steady state) and transmissivity.

Figure 7 Distribution of available pumping test data from the Chalk.

Figure 8 Sub-divisions of the Chalk aquifer.

Figure 9 Distribution of transmissivity data for different regions of the Chalk aquifer.

Figure 10 Distribution of storage coefficient data for different regions of the Chalk aquifer.

Figure 11 Cumulative frequency distributions of transmissivity from pumping tests throughout the Chalk aquifer.

Figure 12 Distribution of (a) transmissivity data and (b) storage coefficient data for Chalk subregions.

Figure 13 The relationship between area medians of transmissivity and storage coefficient throughout the Chalk aquifer. 
Figure 14 Transmissivity estimates from the Kennet Valley related to distance from winter flowing streams.

Figure 15 Distribution of (a) transmissivity and (b) storage coefficient with respect to the degree of confinement of the aquifer. 
Table 1 Summary of borehole and pumping test details for the Chalk of England.

\begin{tabular}{lrrrr}
\hline & $\begin{array}{c}\text { Borehole } \\
\text { depth }(\boldsymbol{m})\end{array}$ & $\begin{array}{c}\text { Casing depth } \\
(\mathbf{m})\end{array}$ & $\begin{array}{c}\text { Diameter } \\
(\mathbf{m m})\end{array}$ & \multicolumn{2}{c}{$\begin{array}{c}\text { Length of test } \\
\text { (hours) }\end{array}$} \\
\hline sample size & 2069 & 1755 & 1951 & 1465 \\
mean & 102 & 40 & 385 & 274 \\
median & 92 & 35 & 305 & 168 \\
25 percentile & 68 & 21 & 200 & 24 \\
75 percentile & 122 & 54 & 460 & 312 \\
\hline
\end{tabular}


Table 2 Summary statistics for the aquifer properties of the Chalk of England.

\begin{tabular}{|c|c|c|c|c|c|c|c|c|c|c|}
\hline \multirow[t]{2}{*}{ Area } & \multirow[t]{2}{*}{ Code } & \multirow{2}{*}{$\begin{array}{c}\text { No of } \\
\text { localities }\end{array}$} & \multicolumn{4}{|c|}{ Transmissivity $\left(m^{2} / d\right)$} & \multicolumn{4}{|c|}{ Storage Coefficient } \\
\hline & & & $\begin{array}{l}\text { No of } \\
\text { tests }\end{array}$ & median & $25 \%$ & $75 \%$ & $\begin{array}{l}\text { No of } \\
\text { Tests }\end{array}$ & median & $25 \%$ & $75 \%$ \\
\hline Dorset & Do & 41 & 52 & 985 & 150 & 2580 & 27 & 0.0052 & 0.0020 & 0.016 \\
\hline Salisbury Plain & SP & 13 & 23 & 1600 & 450 & 3300 & 22 & 0.01 & 0.001 & 0.016 \\
\hline Hampshire & $\mathrm{Ha}$ & 29 & 63 & 2600 & 840 & 6100 & 53 & 0.009 & 0.005 & 0.017 \\
\hline South Downs & SD & 28 & 45 & 440 & 230 & 1600 & 22 & 0.0022 & 0.00061 & 0.004 \\
\hline Kennet Valley & $\mathrm{KV}$ & 74 & 117 & 830 & 380 & 1500 & 107 & 0.0075 & 0.004 & 0.017 \\
\hline Chilterns & $\mathrm{Ch}$ & 44 & 62 & 860 & 276 & 2100 & 44 & 0.0029 & 0.0008 & 0.028 \\
\hline Thames & Th & 81 & 88 & 230 & 44 & 990 & 41 & 0.0024 & 0.0004 & 0.0047 \\
\hline North Downs & ND & 41 & 57 & 670 & 350 & 1600 & 35 & 0.0036 & 0.001 & 0.015 \\
\hline Hertfordshire & $\mathrm{He}$ & 19 & 23 & 580 & 160 & 1000 & 23 & 0.004 & 0.0016 & 0.023 \\
\hline Cambridgeshire & $\mathrm{Ca}$ & 81 & 125 & 800 & 323 & 1500 & 80 & 0.0058 & 0.0011 & 0.012 \\
\hline West Suffolk & ws & 194 & 256 & 780 & 302 & 1750 & 134 & 0.0035 & 0.00087 & 0.011 \\
\hline West Norfolk & WN & 40 & 45 & 1000 & 169 & 1880 & 22 & 0.004 & 0.002 & 0.0067 \\
\hline East Norfolk & EN & 337 & 454 & 250 & 101 & 761 & 205 & 0.0022 & 0.00047 & 0.0078 \\
\hline East Suffolk & ES & 84 & 110 & 315 & 69 & 868 & 61 & 0.0025 & 0.00093 & 0.011 \\
\hline North Essex & NE & 207 & 415 & 400 & 180 & 1100 & 160 & 0.0013 & 0.0005 & 0.0037 \\
\hline Yorkshire & $\mathrm{Y}$ & 68 & 87 & 1250 & 500 & 5970 & 28 & 0.005 & 0.0015 & 0.018 \\
\hline Lincolnshire & $\mathrm{L}$ & 42 & 55 & 1640 & 895 & 3750 & 47 & 0.00023 & 0.000052 & 0.0023 \\
\hline
\end{tabular}


Table 3. Descriptive statistics for transmissivity and storage coefficient measured from pumping tests undertaken in confined, semi-confined and unconfined conditions.

\begin{tabular}{lllllll}
\hline & \multicolumn{3}{c}{ Transmissivity $\left(\boldsymbol{m}^{\mathbf{2}} / \boldsymbol{d}\right)$} & \multicolumn{2}{c}{ Storage coefficient } \\
& confined & Semi-confined & unconfined & confined & Semi-confined & unconfined \\
\hline No of tests & 328 & 194 & 415 & 182 & 137 & 286 \\
Median & 217 & 279 & 923 & 0.00064 & 0.002 & 0.008 \\
25 percentile & 66 & 115 & 310 & 0.00027 & 0.00061 & 0.0028 \\
$\mathbf{7 5}$ percentile & 620 & 720 & 2250 & 0.0035 & 0.011 & 0.017 \\
\hline
\end{tabular}




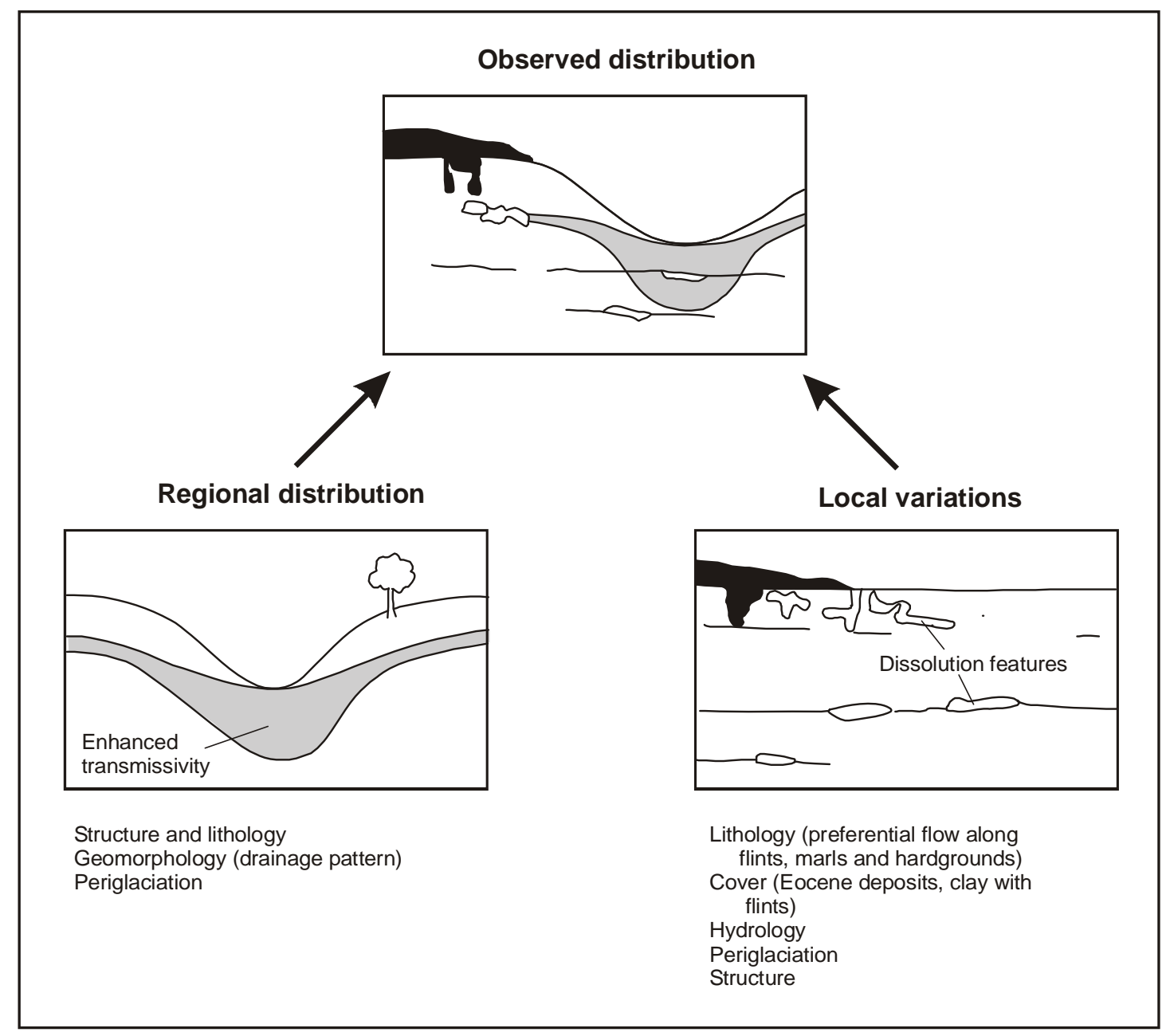

Figure 1

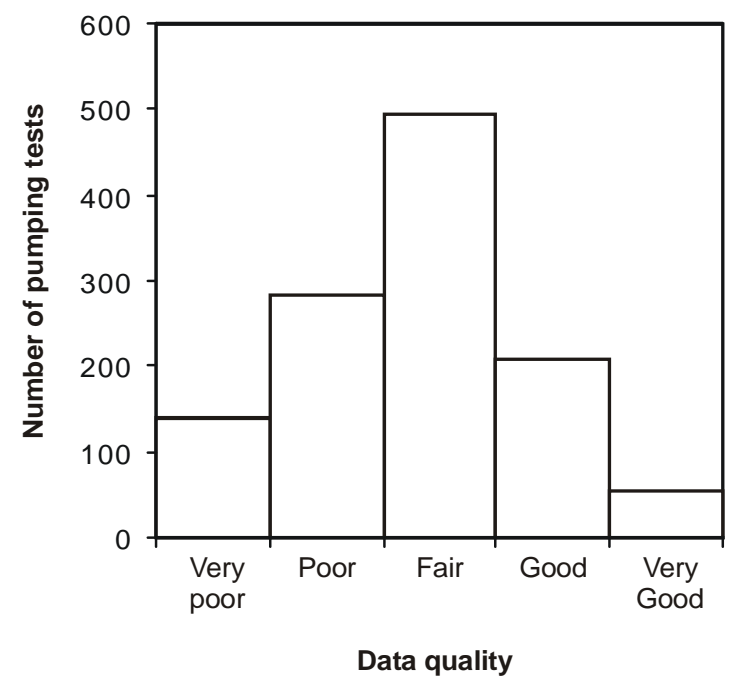

Figure 2 


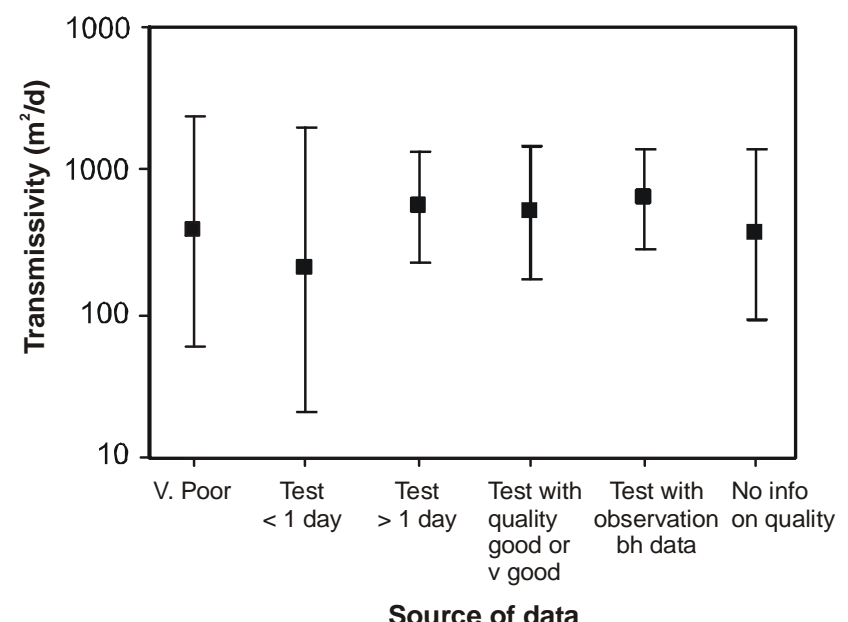

Figure 3

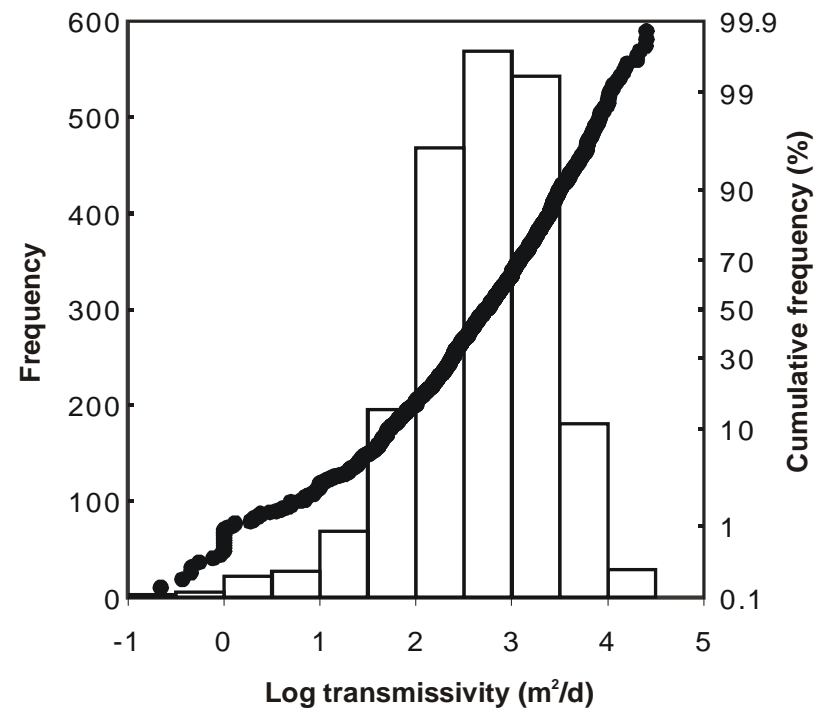

Figure 4

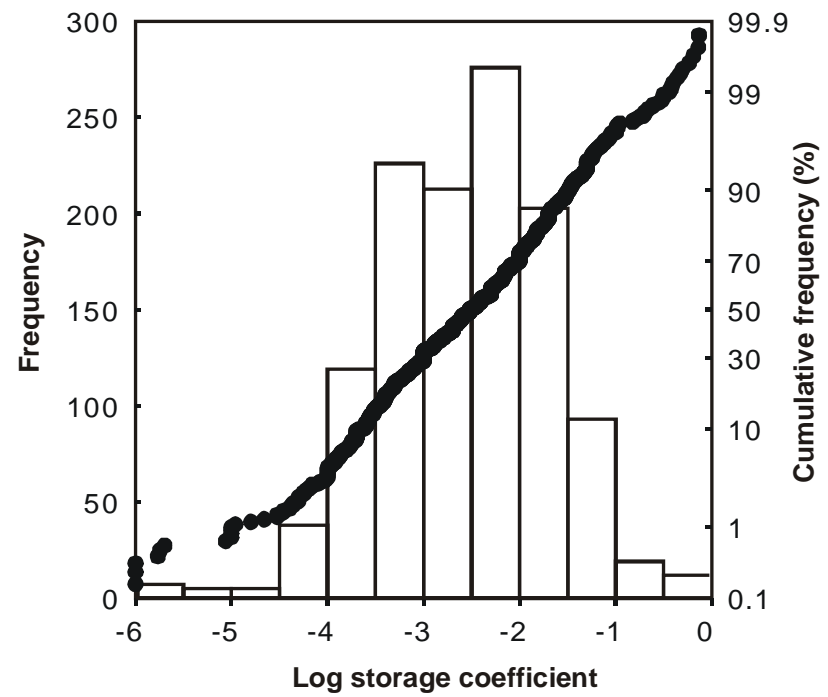

Figure 5 


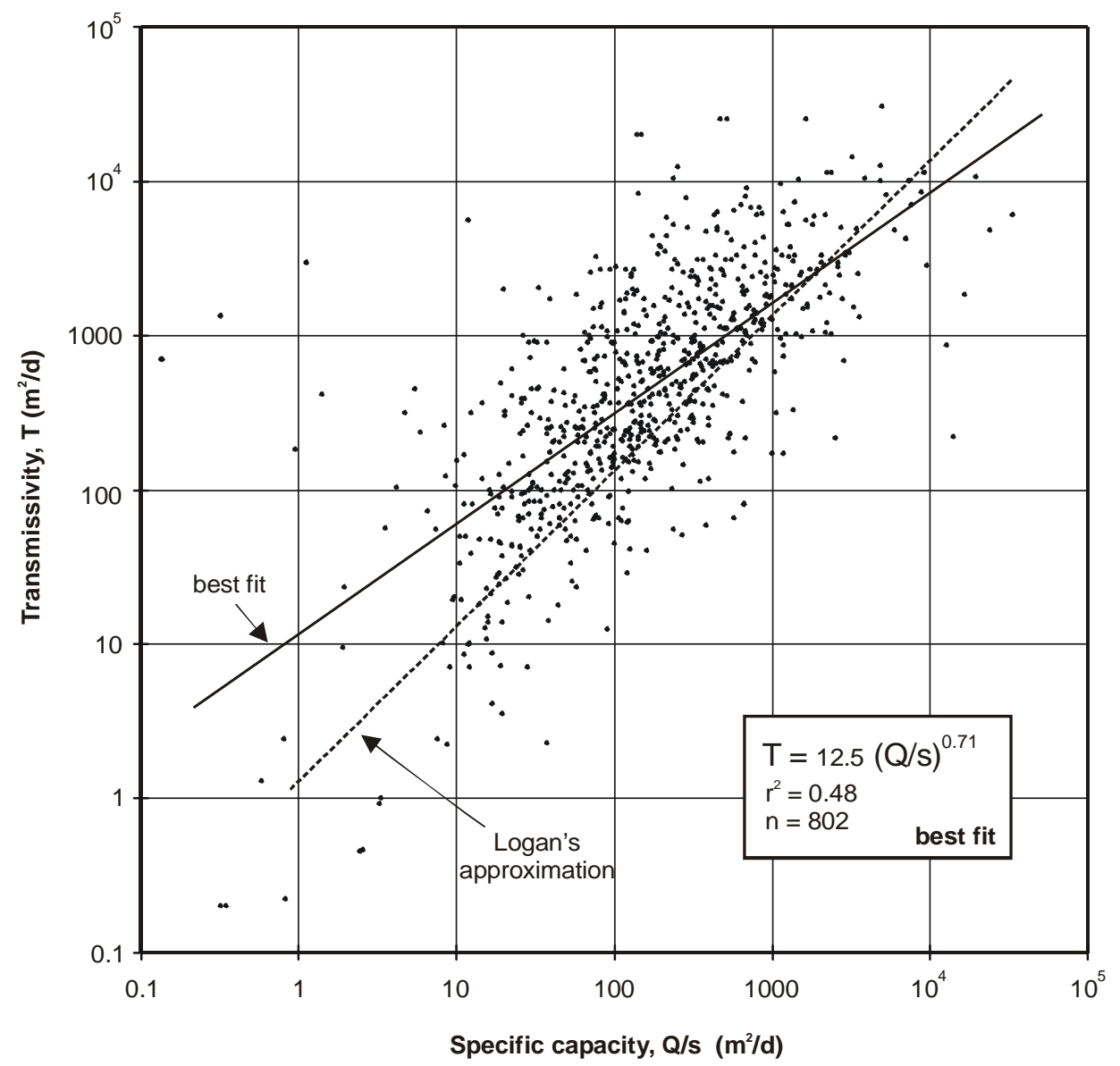

Figure 6

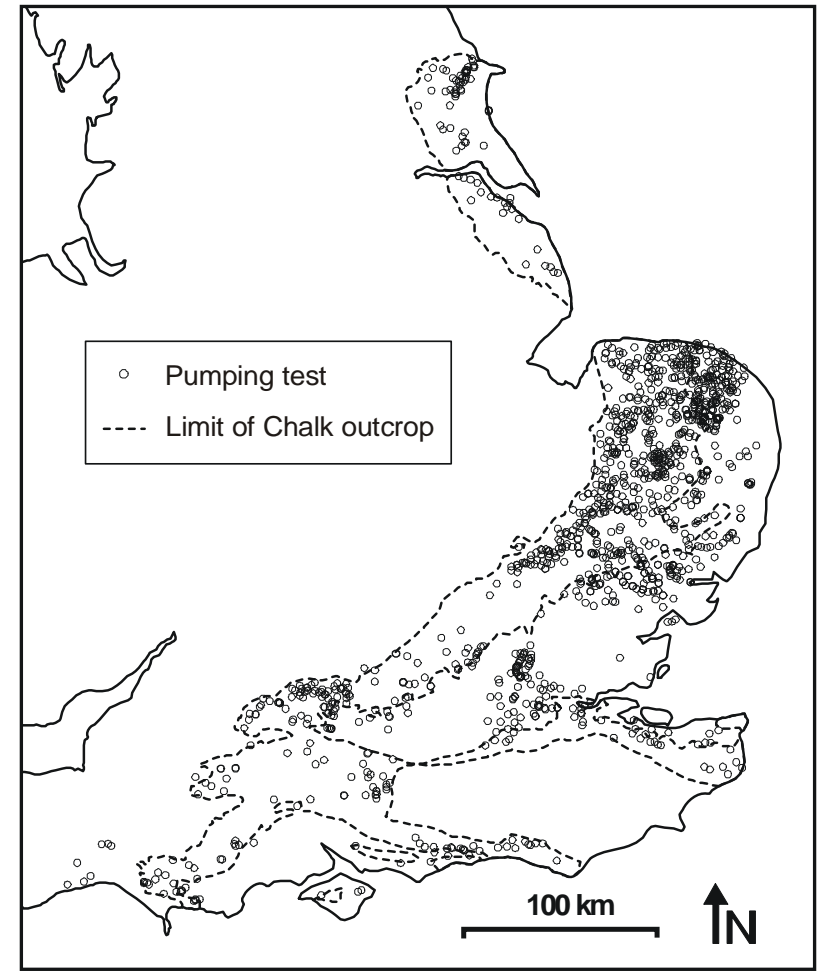

Figure 7 


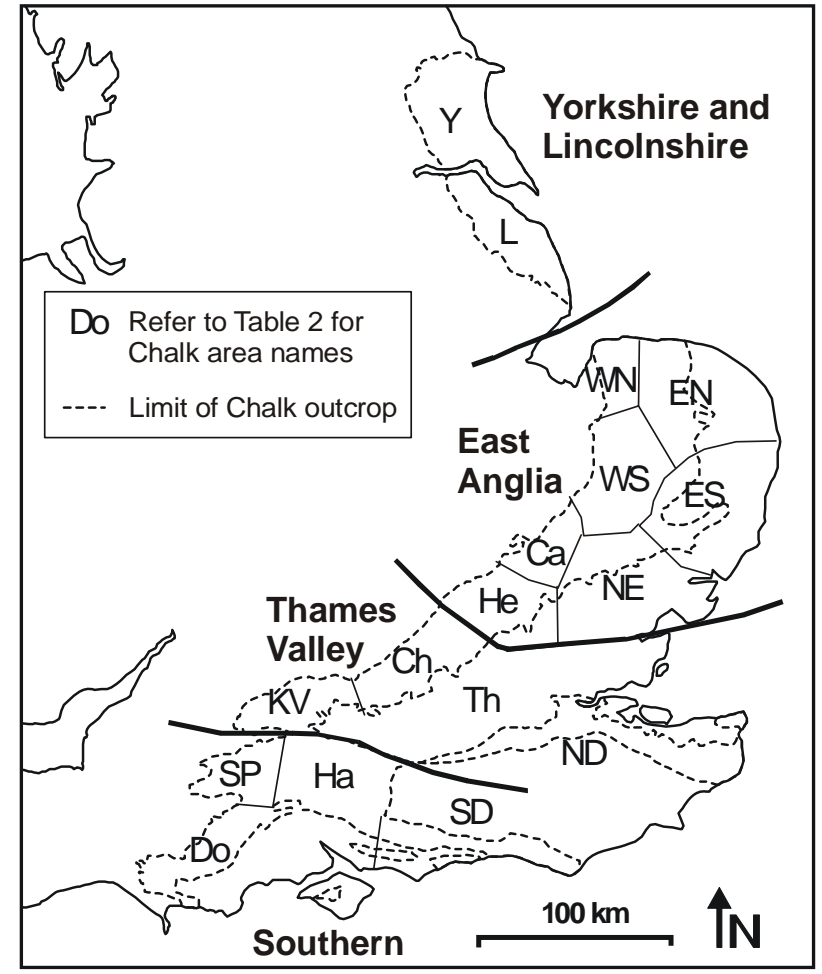

Figure 8
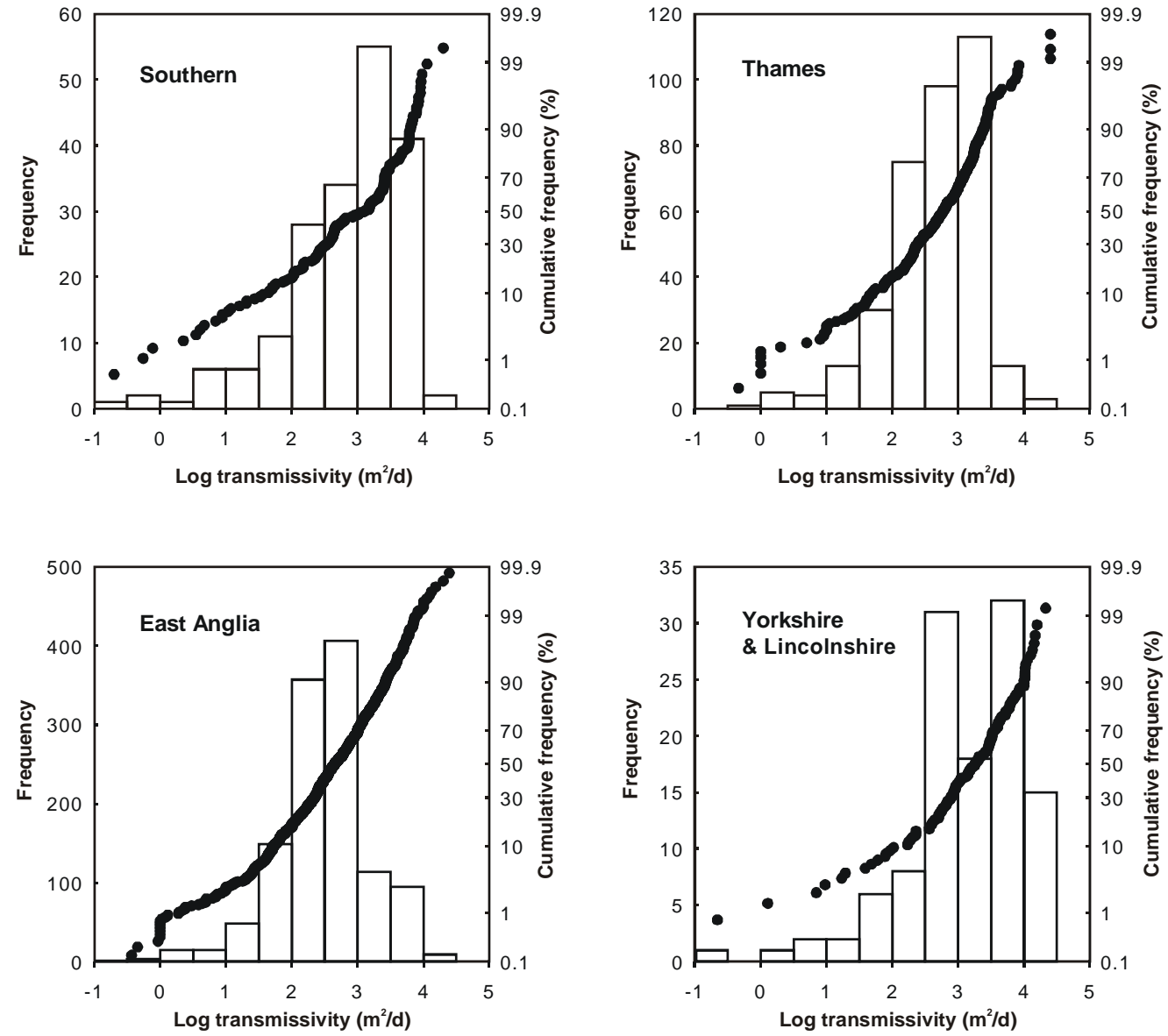

Figure 9 

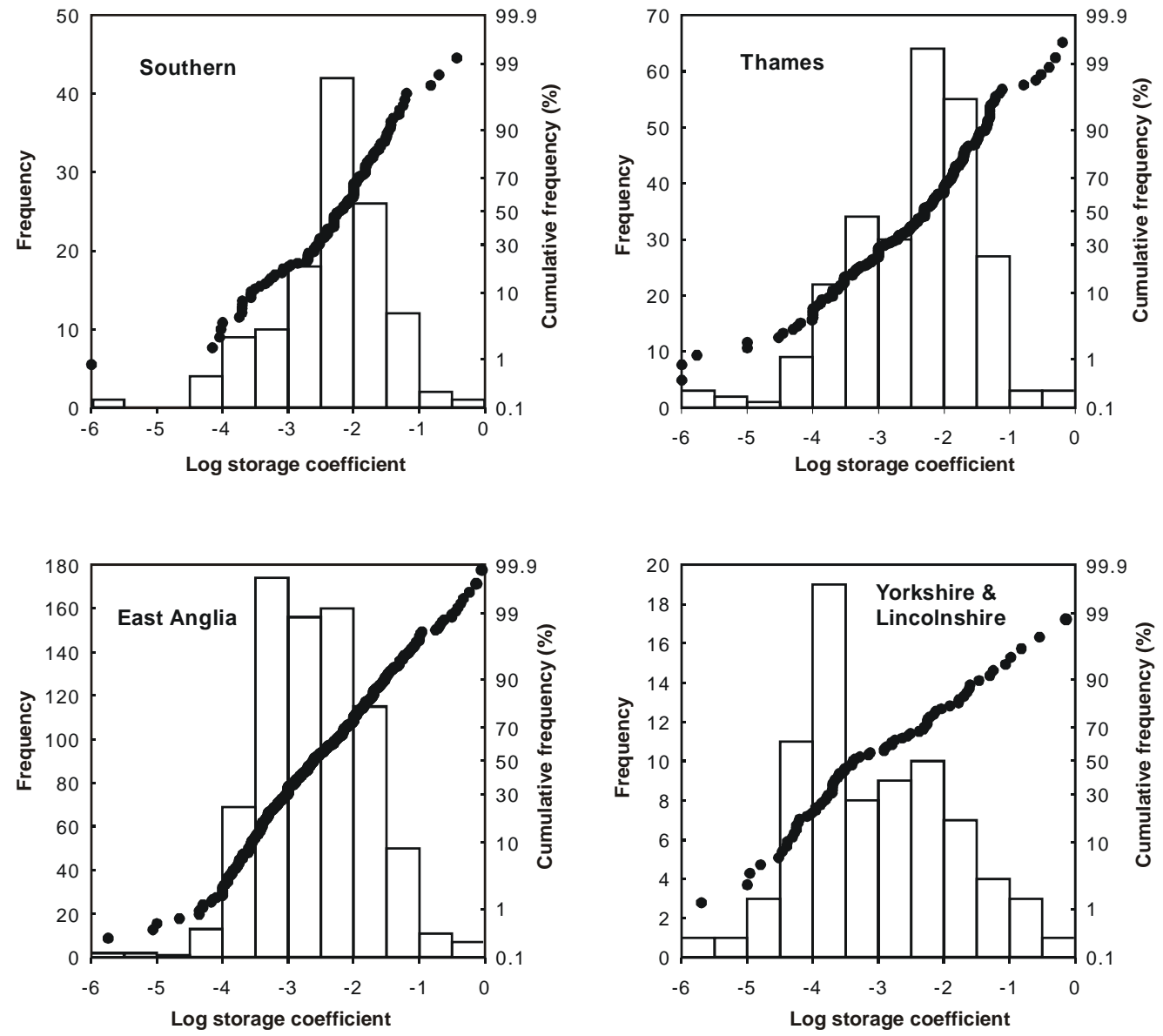

Figure 10

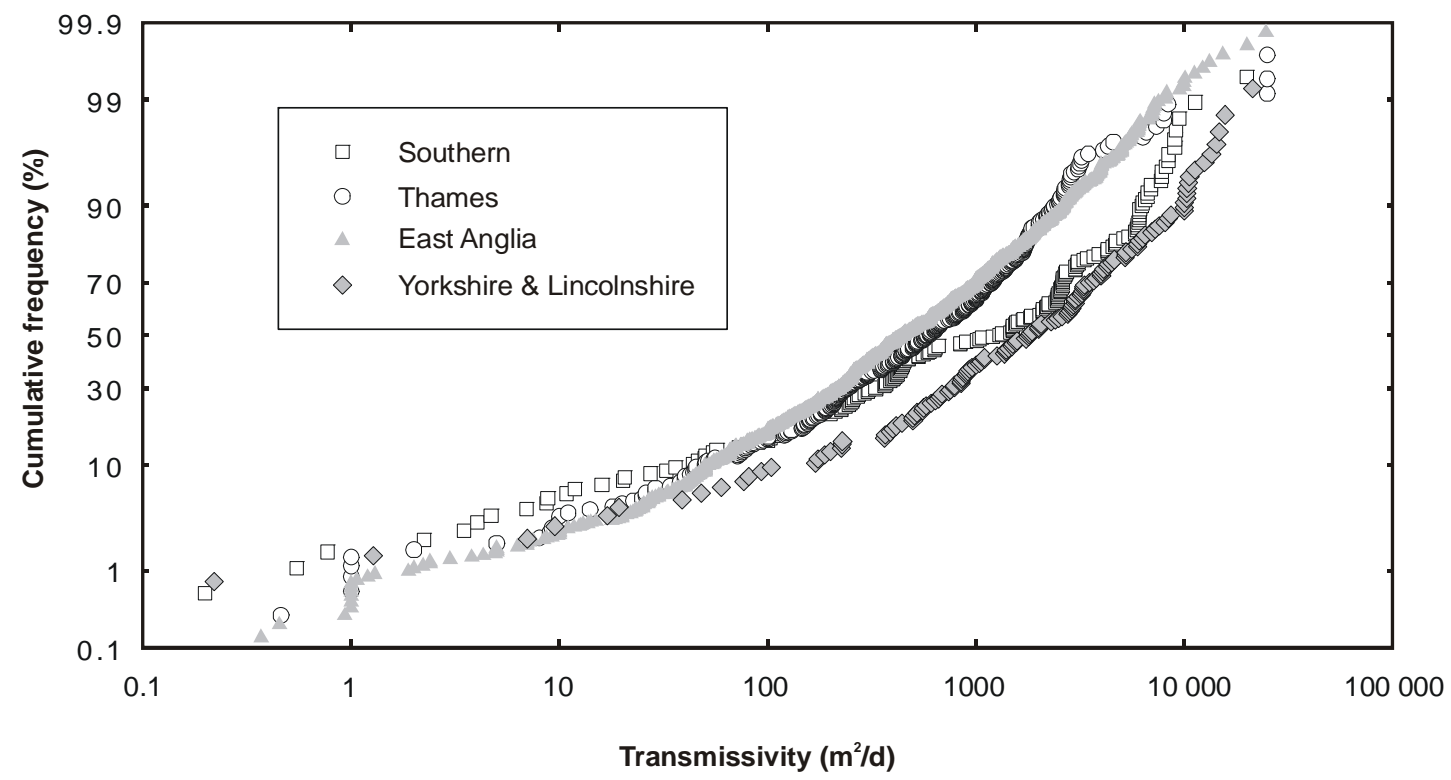

Figure 11 
(a)

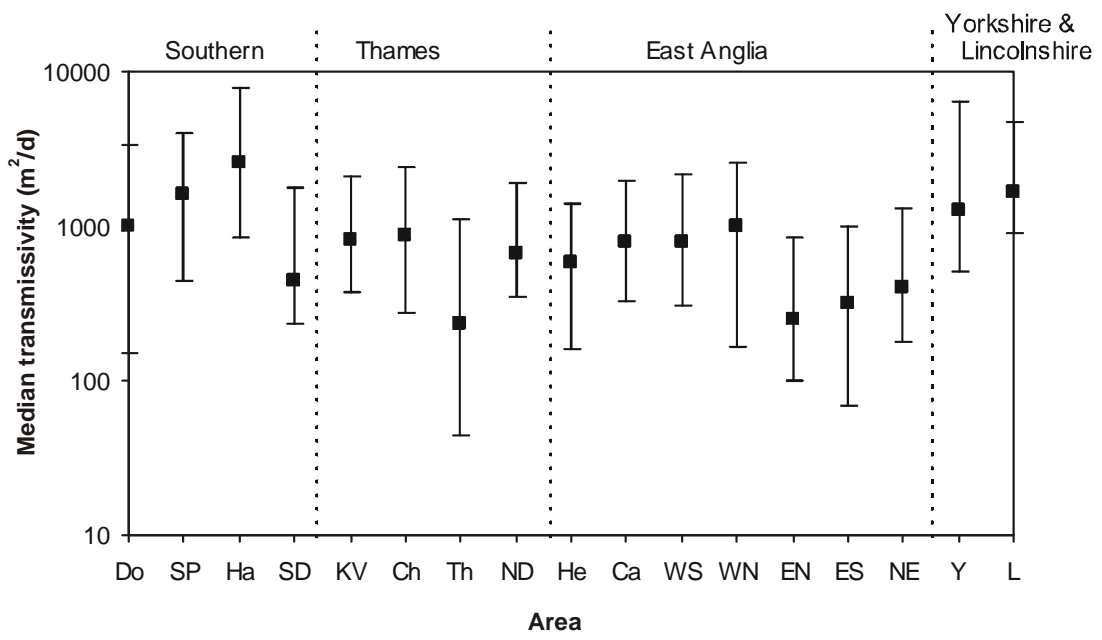

(b)

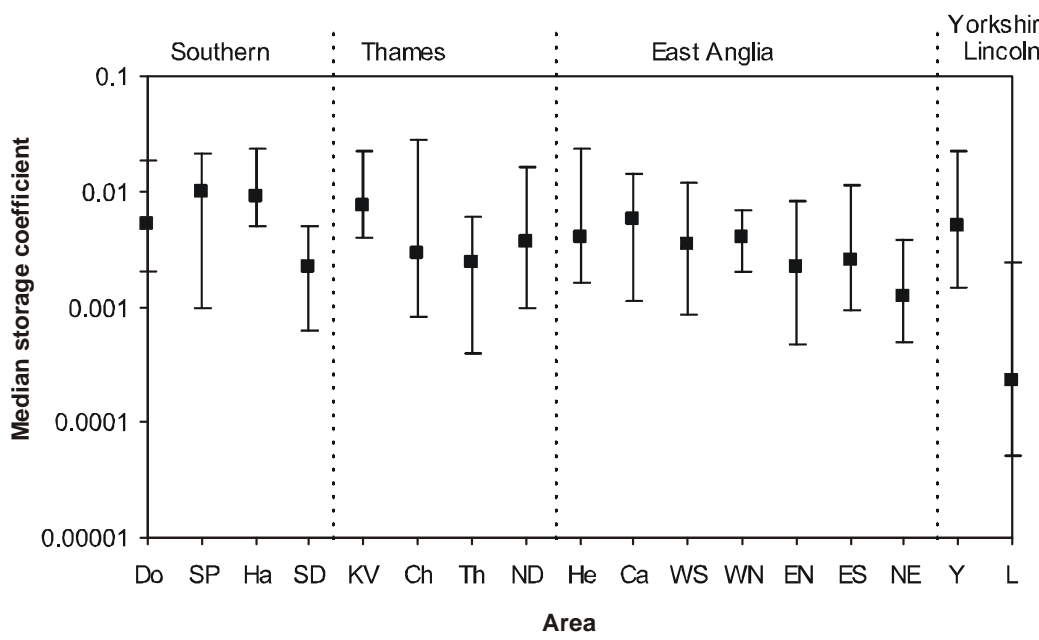

Figure 12

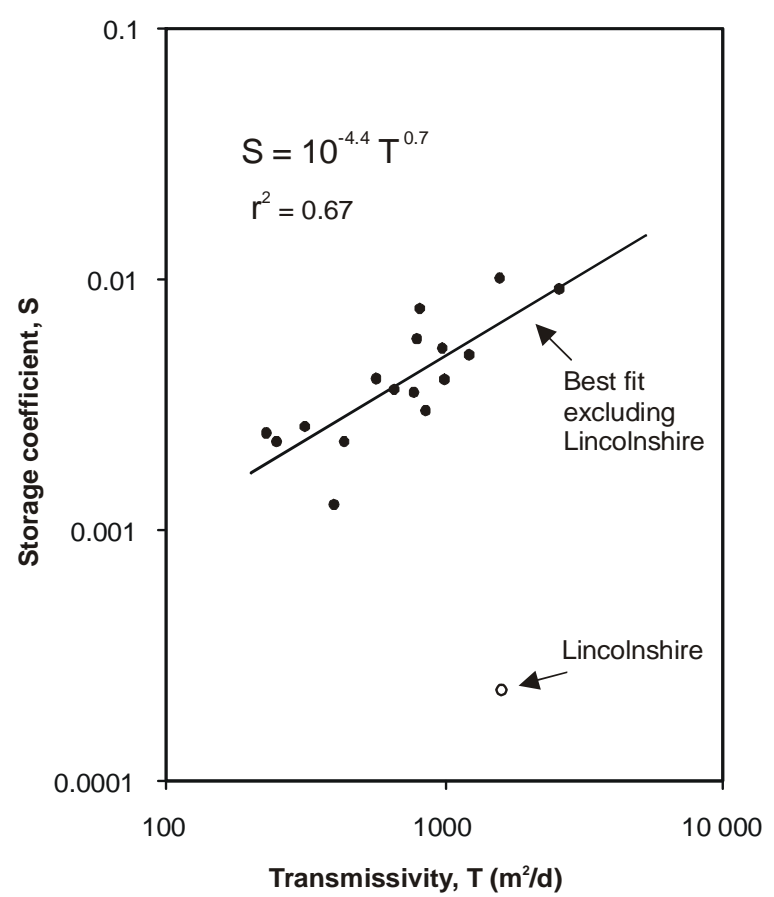

Figure 13 


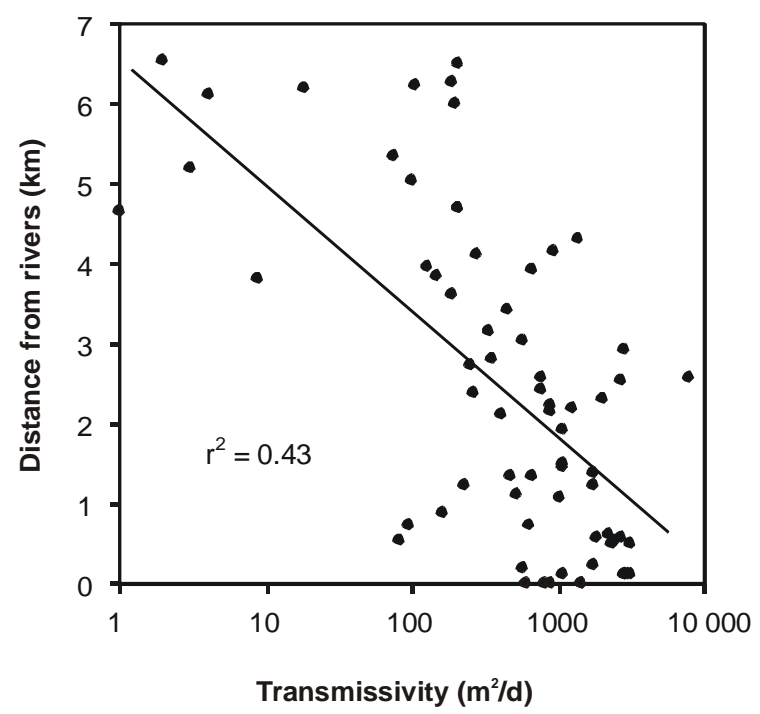

Figure 14

(a)

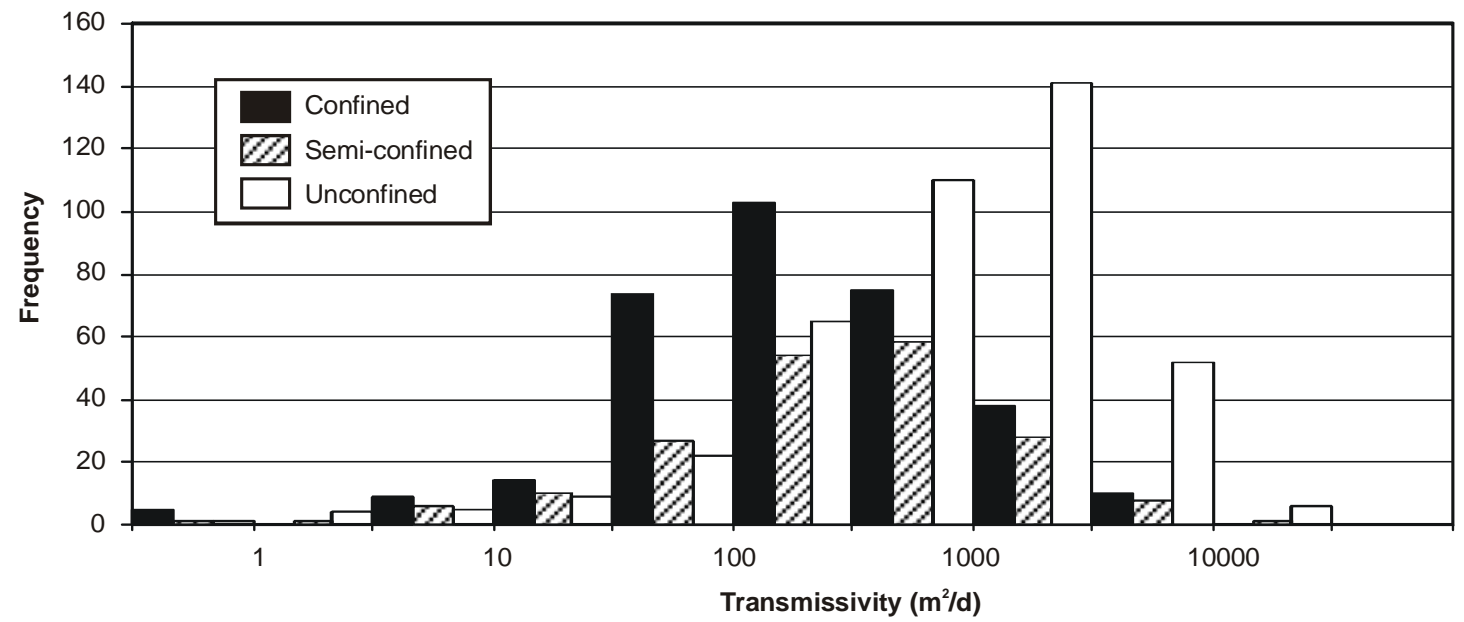

(b)

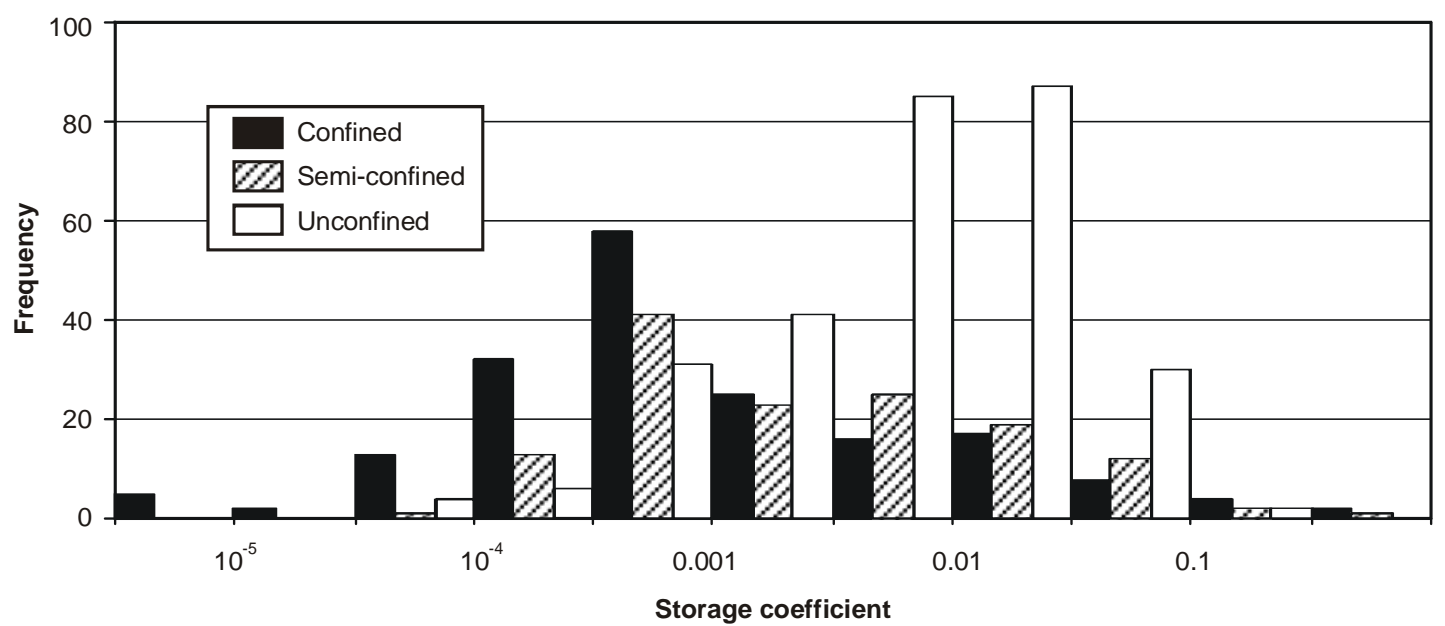

Figure 15 